\title{
Servitization Decision-Making Framework for Thai Manufacturing Companies
}

\author{
Jasseda Lertsakthanakun ${ }^{1}$, Natcha Thawesaengskulthai ${ }^{2}$ \& Chaipong Pongpanich $^{3}$ \\ ${ }^{1}$ Technopreneurship and Innovation Management Program, Chulalongkorn University, Thailand \\ ${ }^{2}$ Industrial Engineering Department, Chulalongkorn University, Thailand \\ ${ }^{3}$ Sasin Graduate Institute of Business Administration, Chulalongkorn University, Thailand \\ Correspondence: Natcha Thawesaengskulthai, Industrial Engineering Department, Chulalongkorn University, \\ Phyathai Rd., Patumwan Bangkok 10330, Thailand. Tel: 66-2-218-6822. E-mail: natcha.t@chula.ac.th
}

Received: March 16, 2012 Accepted: April 5, 2012 Online Published: June 16, 2012

doi:10.5539/ijbm.v7n12p147 URL: http://dx.doi.org/ijbm.v7n12p147

\begin{abstract}
The purpose of this paper is to develop a framework of relevant factors that a company can use to evaluate its suitability for servitization. Semi-structured interviews were conducted with four Thai companies; literature concerning dynamic capability was reviewed to determine the most relevant factors for pursuing servitization. Four case studies were performed to generate a proposed framework. The Delphi method was subsequently applied to verify the decision framework. Finally, a survey of 264 manufacturing companies in Thailand was conducted. The servitization decision framework derived from this research is divided into two structures: servitization concerns and servitization readiness. The servitization decision-making framework facilitates upper management decision making.
\end{abstract}

Keywords: servitization/servitisation, dynamic capability, servitization decision

\section{Introduction}

Servitization, combining product and service offerings as an integrated value, has become increasingly popular in both academic research and business practice (Vandermerwe \& Rada, 1988). Servitization provides values that enable companies to respond effectively to business conditions and to formulate competitive advantages to overcome market obstacles (Mathieu, 2001). Adding services to support products can differentiate a company's offerings and delay the commoditization effect of a product (Correa, Ellram, Scavarda \& Cooper, 2007).

According to Mont (2000), companies may face cultural shifts and corporate challenges in the process of developing servitization strategies. The transition requires companies to alter their strategies, key capabilities, organizational form, company culture and the attitudes of its employees (Brady, Davies \& Gann, 2005). Numerous challenges such as marketing, production, delivery, servitization design, communication and relationship are evident in the product-service shift (Brax, 2005). In fact, the pitfalls of exploiting servitization improperly can include creditability loss, service quality erosion and service paradox, when investments in supporting services exceed anticipated revenues (Gebauer, Fleisch \& Friedli, 2005). To avoid these potential failures in servitization transformation, manufacturing firms must consider relevant factors before deciding on servitization.

Few guidelines that firms can utilize for servitization are available (Baines, Lightfoot, Benedettini \& Kay, 2009). Davies (2006) suggests that companies need to know what they do well and what new capabilities they need to develop. Alliances with suppliers should be organized (Mathieu, 2001) and customer input should be arranged (Gebauer, Bravo-Sanchez \& Fleisch, 2008). Even with these recommendations, there is no explicit list of factors that a company should consider when making the decision towards servitization. This has particular importance in Asia.

Manufacturing conditions in Asia are rapidly changing. Over $70 \%$ of companies in Thailand are now in the manufacturing sector. The World Bank has upgraded Thailand's income categorization from a lower-middle income to an upper-middle income economy ("Thailand now", 2011). Thailand is no longer a low cost manufacturer like China. In terms of innovation, Thailand ranks 48th compared to a highly innovative country like Japan ( $20^{\text {th }}$ on the global innovation index) ("INSEAD issues", 2011). The servitization ratio of companies 
in Thailand has increased from $18 \%$ to $24 \%$ in the last three years. This servitization rate is still low compared to similar countries in the region such as Malaysia and Taiwan (Neely, 2011).

Although Thai manufacturing companies may perceive servitization as a viable business option, numerous aspects must be considered. An effective framework is required to facilitate the decision-making process involved in the shift towards servitization. This research develops a framework of relevant factors that a company can use to evaluate its suitability for servitization. The framework facilitates top management decision making and promotes increased application of servitization.

\section{Methodology}

The research design for developing a servitization decision-making framework consists of four phases as depicted in Figure 1.

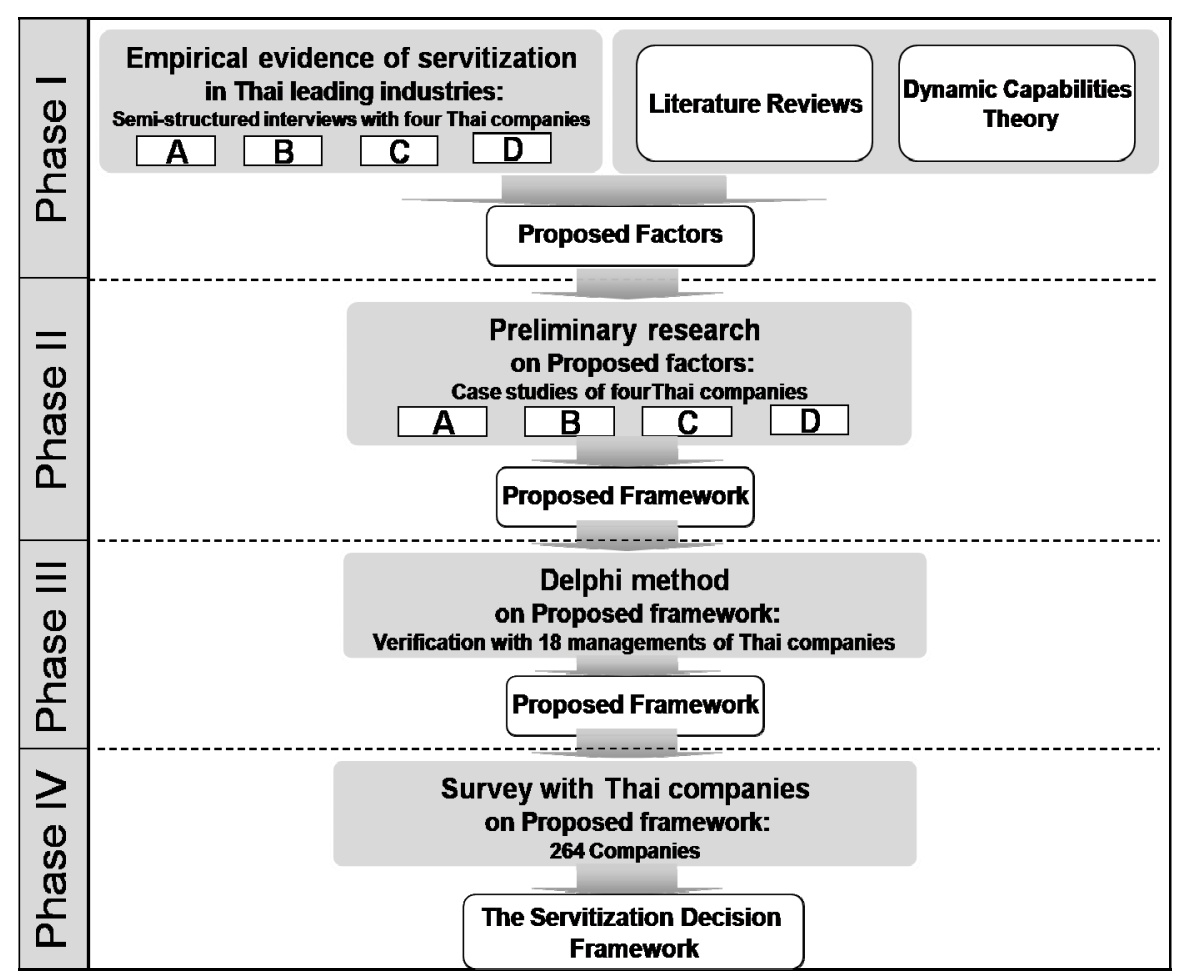

Figure 1. Research methodologies

\subsection{Phase I}

To investigate the relevant aspects that companies should consider during the servitization decision-making process, this research explored viewpoints from Thai companies, literature review and theoretical background. To garner opinions concerning servitization implementation in Thailand, semi-structured interviews were conducted with top management and policy makers of four leading companies.

\subsection{Phase II}

Thai companies from four industries were selected because of their valuable contribution to the Thai economy. These include the automotive, furniture, jewellery and home equipment industries. The auto industry generates over $10 \%$ of Thai GDP and has grown continuously regardless of economic conditions. The furniture industry employs over 300,000 workers and has been affected by the ASEAN free trade area (AFTA) which will begin to allow foreign furniture imported into Thailand without taxation by 2015. This industry will therefore become more competitive. The jewellery industry is one of the top ten Thai export industries and the government is promoting Thailand as an important jewellery centre. Finally, the home equipment industry is important to Thailand for expanding cities. Details concerning the selected companies are shown in Table 1. 
Table 1. General information of companies

\begin{tabular}{|c|c|c|c|c|}
\hline & $\begin{array}{l}\text { Aotomotive } \\
\text { company }\end{array}$ & $\begin{array}{l}\text { Furniture } \\
\text { company }\end{array}$ & $\begin{array}{l}\text { Jewelry } \\
\text { company }\end{array}$ & $\begin{array}{l}\text { Home equipment } \\
\text { company }\end{array}$ \\
\hline Turnover & 100Million dollars & 170Million dollars & 25 Million dollars & 740 Million dollars \\
\hline $\begin{array}{l}\text { Year of } \\
\text { establishment }\end{array}$ & 1998, 14 years & 1968, 44 years & 1993, 19 years & 1996, 16 years \\
\hline $\begin{array}{l}\text { Number of } \\
\text { employees }\end{array}$ & 400 & 4,000 & 170 & 6,900 \\
\hline $\begin{array}{l}\text { Industry rank by } \\
\text { revenue }\end{array}$ & Top3 & Top3 & Top3 & Top3 \\
\hline Type of business & $\begin{array}{c}\text { Producer, Retailer, } \\
\text { Financial service } \\
\text { provider }\end{array}$ & $\begin{array}{c}\text { Producer, } \\
\text { Wholesaler, Retailer, } \\
\text { Exporter }\end{array}$ & $\begin{array}{l}\text { Producer and } \\
\text { Retailer }\end{array}$ & Producer and Retailer \\
\hline $\begin{array}{l}\text { Characteristics of } \\
\text { industry }\end{array}$ & $\begin{array}{l}\text { Brand owners, } 5 \\
\text { big players }\end{array}$ & $\begin{array}{c}5 \text { big players cover } \\
60 \% \text { of the market } \\
\text { and tens of small } \\
\text { players }\end{array}$ & $\begin{array}{c}\text { Very fragmented, } \\
10 \text { big players and } \\
\text { hundreds of small } \\
\text { players }\end{array}$ & $\begin{array}{c}7 \text { big players cover } \\
75 \% \text { of the market } \\
\text { and tens of small } \\
\text { players }\end{array}$ \\
\hline
\end{tabular}

\subsection{Phase III}

After preliminary research, a servitization decision-making framework was proposed. The Delphi method was used to verify the framework. Skulmoski, Hartman \& Krahn (2007) state that "the Delphi method is an iterative process to collect and distil the anonymous judgments of experts using a series of data collection and analysis techniques interspersed with feedback." Based on Macmillan's research (1971), a panel size of at least 17 people is necessary to ensure the lowest rate of error in Delphi studies. To generalize the framework to suit most Thai industries, the experts were drawn from a diverse range of industries and various sized companies around Thailand. All experts are decision makers in their respective companies. The Delphi tests comprised 18 experts from various industries as shown in Table 2.

Table 2. The Delphi test: expert list

\begin{tabular}{cccccccc}
\hline $\begin{array}{c}\text { Expert } \\
\text { No. }\end{array}$ & Industry & $\begin{array}{c}\text { Turnover } \\
\text { (US\$ million) }\end{array}$ & $\begin{array}{c}\text { Number of } \\
\text { employees }\end{array}$ & $\begin{array}{c}\text { Expert } \\
\text { No. }\end{array}$ & Industry & $\begin{array}{c}\text { Turnover } \\
\text { (US\$ million) }\end{array}$ & $\begin{array}{c}\text { Number of } \\
\text { employees }\end{array}$ \\
\hline 1 & Coal & 35 & 60 & 10 & Textiles & 10 & 100 \\
2 & Paper & 3 & 60 & 11 & Handicraft & 15 & 500 \\
3 & Leather & 1 & 12 & 12 & Auto Parts & 9 & 220 \\
4 & Furniture & 100 & 2500 & 13 & Leather & 4 & 200 \\
5 & Automotive & 220 & 250 & 14 & Furniture & 6 & 170 \\
6 & Beverage & 25 & 600 & 15 & Furniture & 35 & 70 \\
7 & Plastic & 1 & 40 & 16 & Food & 4 & 180 \\
8 & Textiles & 1 & 75 & 17 & Beverage & 18 & 600 \\
9 & Food & 1 & 20 & 18 & Wooden & 3 & 250 \\
\hline
\end{tabular}

The Delphi methods were conducted in two rounds. First, the experts were asked to answer two open-ended questions either in person or by telephone:

1) What factors require your company to provide more services? (Servitization concern)

2) What factors does your company have to consider before you introduce new services to customers? (Servitization readiness)

Responses from experts were checked against the proposed factors to identify any concepts that had not yet been considered in the initial proposal. All responses confirmed the proposal factors and no further factors were added.

During the second round of interviews, experts were asked to weigh the relevance of each factor in the 
servitization decision-making process using the following scale: $0=$ not relevant, $1=$ relevant but not important, $2=$ somewhat important, $3=$ moderately important, $4=$ very important. The expert evaluations were calculated for median, mode and inter-quartile range to determine the validity of the answers. If the statistical results showed dissenting opinion without clear reason, a third round of the Delphi method would be conducted to investigate the discrepancy.

\subsection{Phase IV}

The 21 factors were proposed to members of the federation of Thai industries in a survey. During 2011 and 2012, 1,800 questionnaires were sent out; of these, 264 questionnaires were returned, representing a $15 \%$ response rate.

\section{Findings}

\subsection{Empirical Study: Servitization Decision-Making Factors}

The literature review and theoretical background showed that the decision-making factors could be divided into external and internal factors. External factors consist of customers, competitors, suppliers and macro factors. Several studies explain that customers, competitors and suppliers are important external servitization considerations (Bask, Lipponen, Rajahonka \& Tinnila, 2011; Gebauer et al., 2008; Helander \& Moller, 2008; Lockett, Johnson, Evans \& Bastl, 2010, Mathieu, 2001). Thompson (2002) explains that the PESTEL framework (political, economic, social, technological, environmental, and legal) can effectively analyze a firm's macro environment, as these factors affect the decision making of a company (Bandinelli \& Gamberi, 2012; Gremyr, Lofberg \& Witell, 2010). On the other hand, internal factors represent a company's context and dynamic capabilities. Company context includes a company's vision, strategies, market position, profit, loss, organizational structure and company culture (Brady et al., 2005; Gebauer, Edvardsson \& Bjurko, 2009; Gebauer, Paaiola \& Edvardsson, 2010; Oliva \& Kallenberg, 2003; Sakao, Sandstrom \& Matzen, 2009). Generally, a firm's resources consist of its assets, capabilities, knowledge, tangible and intangible attributes.

In a rapidly changing environment, dynamic capabilities are useful tools to arrange internal company resources needed for competitive advantage (Eisenhardt \& Martin, 2000). Dynamic capabilities help a company overcome business challenges (Teece, Pisano \& Shuen, 1997). Using these capabilities to investigate a company's internal factors can help them address internal difficulties (Mont, 2000; Brady et al., 2005; Vandermerwe \& Rada, 1988). Key aspects of Teece's dynamic capabilities $(1997,2007)$ can be used in conjunction with other views concerning dynamics (Adner \& Helfat, 2003; Ambrosini \& Bowman, 2009; Eisenhardt \& Martin, 2000; Petroni, 1998; Reilly \& Scott, 2010; Verona \& Ravasi, 2003; Zollo \& Winter, 2002). Dynamic capabilities in this study are grouped into positions, paths, sensing processes, seizing processes and transforming processes as shown in Figure 2.

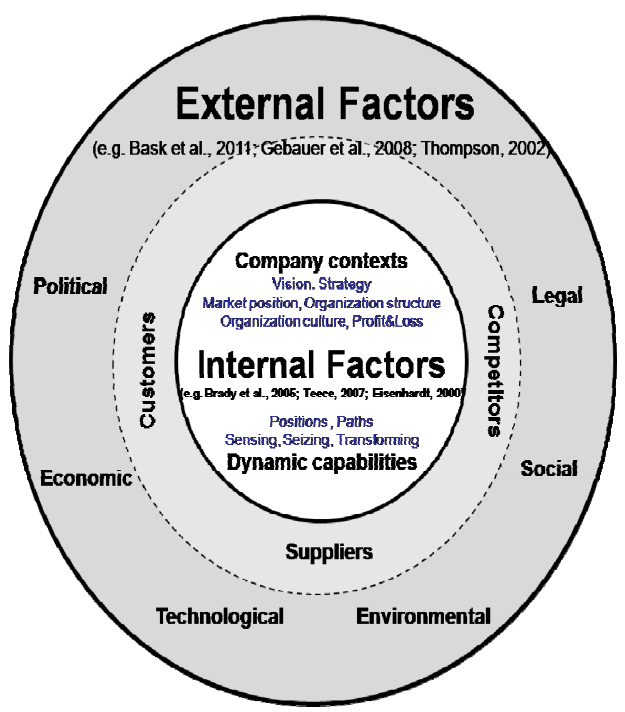

Figure 2. Proposed factors

The four case-study companies consider servitization as a promising business model. Although they have not explicitly defined servitization, they all recognize the value of product and service combination. In today's 
market, it is no longer possible to satisfy customers with products alone. While products are still the primary offerings, service elements are inevitably embraced in their operations. All agree that services expedite customer's purchase decisions and contribute to customer loyalty.

\subsection{Preliminary Research: Relevant Factors in the Servitization Decision-Making Process}

When considering offering additional services, all four companies in the case studies consider internal factors to be more important than external ones as described in the following section.

\subsubsection{External Factors}

Customers are considered the most important external factor with regard to providing more services. First, customers know what services they need. Normally, the top five companies in an industry already offer the services that customers say they want. Therefore, servitization of these kinds of services is not too difficult for companies to develop unless a company pioneers specific services in its industry. Customers can evaluate whether or not services are valuable to them. Top companies normally promote new service offers that competitors do not yet provide. Sometimes, customers do not realize that they need any new services. An innovative service requires customers to evaluate its value and requires companies to competently provide the service. New services in various industries may be resisted. For example, the furniture company was the first in its industry to provide 3D design and on-site inspection services. Initially, customers were reluctant to employ these services. The company had to provide them free of charge as well as promote the benefits. Later, both services became normal in the industry. The next most important external factor is competition.

Unavoidably, companies must observe what new services their key competitors provide to customers because this affects market position and share. While leading companies place less emphasis on their competitors, fast-follower companies consider competitors' moves as key to their servitization decision making. In the automotive industry, the case-study company creates unique services to differentiate it from its competitors; however, it still provides services that have been launched successfully by other players. After competition, the next most external important factor that affects servitization is suppliers.

In the value chain, suppliers affect servitization in many ways. Most importantly, the negotiation power of suppliers can support or hinder services. If raw material suppliers have a strong influence, companies tend to regard services as an alternative way of differentiating their products. Conversely, if technology and supporting assets for providing services come from suppliers who control the value chain, companies may find it difficult to offer additional services. Further, the availability of components or functions relevant to services is part of a company's readiness to servitize. If suppliers are not ready to support them, companies may not be able to launch new services. For instance, the automotive company must confirm that its maintenance agents can support its new 24-hour emergency service. Partnership between companies and suppliers is essential to the success of servitization. If companies create strong collaboration, they are more dynamic in providing new services. Their suppliers help them develop components or capabilities so they can concentrate on their core business and key capabilities. For example, the furniture company has partnered with a software company to develop a specific program to support its new services. Customers, competition and suppliers all exist within a range of broader environmental factors.

Environmental factors consisting of political, economic, social, technological, environmental and legal concerns (PESTEL) are the least important components that companies consider when considering servitization. Servitization generally begins by serving local or current customers, so external factors are less significant. Moreover, every company in a given industry faces the same PESTEL factors. Any environmental pressure affects all companies similarly. PESTEL factors that strongly affect a particular industry influence the degree of servitization of that industry as a whole.

\subsubsection{Internal Factors}

\subsubsection{Company Context}

Within the context of a company, revenue and profit comprise the primary internal factors that influence the decision to pursue servitization. The case-study companies claim that reductions in revenue or profit trigger their need to change. Although they do not completely agree that adding new services can raise profits, they believe that overall revenues normally increase. Profits clearly are related to a company's market position.

Market position can enhance or delay adoption of servitization. In industries where intensive services are offered only by top companies, small companies tend to concentrate on products. Providing more services requires more effort and higher costs that may exceed revenues. Therefore, when services are free of charge, only productive companies can provide them. However, in industries where small companies cannot compete with large 
manufacturing firms in terms of economy of scale and scope, servitization is the best way to distinguish a company. Market position is particularly important for the companies interviewed for this research as they are all in the top three within their respective industries. Differentiating themselves from the competition and maintaining top market positions require constant product and service innovations. Servitization is inevitable for most top firms; however, the degree of servitization may vary depending on the type of industry and its norms.

Although external factors such as customers and competitors may force companies to servitize, the actual decision to transform comes from management. If management perceives that servitization is essential to the focus of the company, more services are added. As the furniture company interviewee explains, "We can't wait until customers say what they want or until competitors offer certain services, because sometimes our customers don't know what services they want. The thing is, our competitors don't provide those services because they aren't as innovative as we are."

\subsubsection{Dynamic Capabilities}

All four case-study firms agree that the five aspects of dynamic capabilities are of equal significance. However, each feature is important at different times. In the beginning, sensing processes are most important to lead companies to new opportunities. With their position and path, companies can decide whether or not to seize new opportunities. Finally, transforming processes complete the initiation of servitization to ensure its success. Each of the dynamic capabilities is explored in the following section.

Assets in several areas create a company's position. Technology, knowledge, reputation and structural assets are the most frequently recognized positions that facilitate servitization. Offering new services requires technology and supporting assets as well as new knowledge to deliver services effectively. As the furniture company provides a new 3D design program in all its shops, a customized software program and knowledgeable staff members are the keys to its success. In generating new services, reputation assets help a company enhance customer confidence and collaborate with suppliers. Organizational structure and management style also support servitization. The case-study companies revealed no consensus concerning the best organizational form for servitization. Rather, a flexible but controllable structure adapted to each company's culture and circumstances is considered more suitable than an ideal organizational form. Management styles such as formal or informal, tight or loose, depend on specific functions. However, the structure and supervision that support collaboration such as cross-function teams and overall performance evaluation can raise a company's dynamic capabilities.

Past success, current assets and potential investment create the dynamic capability defined as a company's path. For example, the jewellery company in this research won the "super brand" award for effectively satisfying customers. Consequently, its customers feel more confident about its new services because they believe in its product quality and reliable service. Owning the largest number of shops in Thailand, the company's new consulting service can be more efficiently accessed by customers. Its planned investment in a database further supports a higher level of customer service. Following a company's position and path leads to consideration of its sensing processes.

Sensing processes require keen sensing abilities among top managements. In most top-three companies, leaders have a strong awareness of changes affecting their companies and industries. Although most service shifts in the four case companies occurred due to the awareness of management, it is better if this ability expands to companies' managers and employees so they can more rapidly discern changes and opportunities in the environment such as customers, suppliers and competitors with whom they have direct contact. Supporting structures and processes such as R\&D units, close collaboration with suppliers, constant information access to the market and technology fortify a company's overall sensing ability.

Seizing processes comprise the next dynamic capability. These processes require investment and strategies in order for services to be provided in a timely manner. The ability to capture opportunities is demonstrated at the executive level to establish the direction of the company direction and on the managerial level to support the seizing function. Management selects the area for its company's business and facilitates the assets and abilities required for creation of additional services. Key managers establish proper tactical and operation details to serve the company's strategy. Though seizing processes may not involve all people in the company, this ability should be part of the company's culture so that no one neglects any opportunities that arise and everyone is willing to assist any new strategy or operation.

The final stage of dynamic capability involves transforming processes. Sensing and seizing processes bring opportunities to companies and initiate change while transforming processes prolong the success of servitization. While cost, time and quality are the main areas of attention in manufacturing, providing more services requires a service mindset. Before initiating servitization in a manufacturing company, management should determine the 
optimum level of cost, time, quality and service. If the focus of attention is not clear, employees may not alter their operational goal from the original manufacturing mindset, which would hinder the success of servitization. As services offered by manufacturing companies require more effort to operate, knowledge management is a vital transformation practice. Supporting individual learning, promoting knowledge sharing and integration plus creating an organizational learning culture all prepare employees for servitization. When the level of servitization increases, coordination becomes a significant transforming process. For instance, the home equipment company explains that its services are not only handled by staff who contact customers directly, but also require commitment and support from other departments. To subsidize the extra costs incurred by providing additional services, companies should encourage reconfiguration practices so that staff can replicate, transfer or restructure resources properly. While decentralization is claimed to be one of the transforming processes, all cases show that centralization remains the management scheme in use. Although the case study managers agree that decentralized firms demonstrate greater flexibility, a centralized structure allows rapid decision making and direction from the top. Thus, centralization does not impede servitization as claimed by some researchers.

\subsection{Delphi Method: Verification of the Servitization Decision-Making Framework}

The proposed factors weighted by 18 business experts were calculated for statistical data including median, mode and inter-quartile range as shown in Table 3.

Table 3. Statistical results of proposed factors from Delphi method

\begin{tabular}{|c|c|c|c|c|c|c|c|}
\hline Delphi Result & Median & Level of Importance & Mode & Q1 & Q3 & $\begin{array}{l}\text { Inter-quartile } \\
\text { Range (IQR) }\end{array}$ & Difference of opinion \\
\hline \multicolumn{8}{|l|}{ Servitization Concern } \\
\hline \multicolumn{8}{|l|}{ 1. Company context } \\
\hline F1 Revenue/Profit & 3.44 & very important & 4 & 3 & 4 & 1 & barely different \\
\hline F2 Marketing position/image & 3.22 & very important & 4 & 3 & 4 & 1 & barely different \\
\hline $\begin{array}{l}\text { F3 Vision/ Policy from Management } \\
\text { 2. Customers }\end{array}$ & 3.67 & very important & 4 & 4 & 4 & 0 & similar \\
\hline F4 Services that customers want & 3.83 & very important & 4 & 4 & 4 & 0 & similar \\
\hline $\begin{array}{l}\text { F5 Services that customers value } \\
\text { 3. Competitors }\end{array}$ & 3.28 & very important & 4 & 3 & 4 & 1 & barely different \\
\hline $\begin{array}{l}\text { F6 Services that competitors provide } \\
\text { 4. Suppliers }\end{array}$ & 2.78 & moderately important & 3 & 2 & 3 & 1 & barely different \\
\hline $\begin{array}{l}\text { F7 Negotiation power with supplier } \\
\text { 5. Environment }\end{array}$ & 2.50 & moderately important & 2 & 2 & 4 & 1.75 & somewhat different \\
\hline F8 Politic & 1.83 & somewhat important & 1 & 1 & 3 & 2 & somewhat different \\
\hline F9 Economic & 2.72 & moderately important & 3 & 2 & 3 & 0.75 & similar \\
\hline F10 Social & 2.44 & moderately important & 3 & 2 & 3 & 1 & barely different \\
\hline F11 Technology & 3.00 & moderately important & 3 & 3 & 3 & 0 & similar \\
\hline F12 Environment & 2.56 & moderately important & 3 & 2 & 3 & 1 & barely different \\
\hline F13 Legal & 3.11 & moderately important & 3 & 3 & 4 & 1 & barely different \\
\hline Servitization Readiness & & & & & & & \\
\hline 1. Dynamic capabilities & & & & & & & \\
\hline F14 Company position \& assets & 2.44 & moderately important & 3 & 2 & 3 & 1 & barely different \\
\hline F15 Company opportunities & 3.39 & very important & 4 & 3 & 4 & 1 & barely different \\
\hline F16 Sensing capabilities & 3.11 & moderately important & 3 & 3 & 3 & 0 & similar \\
\hline F17 Seizing capabilities & 3.33 & very important & 3 & 3 & 4 & 1 & barely different \\
\hline $\begin{array}{l}\text { F18 Transforming capabilities } \\
\text { 2. Customers }\end{array}$ & 3.56 & very important & 4 & 3 & 4 & 1 & barely different \\
\hline $\begin{array}{l}\text { F19 Services that customers value } \\
\text { 3. Suppliers }\end{array}$ & 3.17 & moderately important & 4 & 3 & 4 & 1 & barely different \\
\hline
\end{tabular}


F20 Availability of materials, equipment or supporting duty from suppliers 3.00 moderately important $\begin{array}{lll}3 & 3 & 4\end{array}$ 0.75 similar F21 Cooperation with suppliers

3.17 moderately important $3 \quad 3 \quad 4$

1

barely different

\begin{tabular}{lclc}
\hline Median & Importance level of factor & IQR & Difference of opinion \\
\hline $3.21-4.00$ & very important & $3.21-4.00$ & very different \\
$2.41-3.20$ & moderately important & $2.41-3.20$ & moderately different \\
$1.61-2.40$ & somewhat important & $1.61-2.40$ & somewhat different \\
$0.81-1.60$ & relevant but not important & $0.81-1.60$ & barely different \\
$0.00-0.80$ & not relevant & $0.00-0.80$ & similar \\
\hline
\end{tabular}

The median score of factors ranges from 1.83 to 3.83. Since 1 is the minimum weight to show that a factor is relevant, the Delphi method verifies that all proposed factors are relevant to servitization. The median score of all factors is higher than 1.60. Thus, most factors can be described as somewhat important to the servitization decision making of a company.

The smallest median value is 1.83 for the political factor. The mode is 1 ; the 1 st quartile and 3rd quartile are 1 and 3, respectively. The statistics show that the political factor is relevant, but not important, to most experts in this study. However, some experts consider politics to be moderately important. The highest median value is 3.83 for the factor of services that customers need. The mode is 4 ; the $1^{\text {st }}$ quartile and $3^{\text {rd }}$ quartile both measure 4 . Therefore, most cases consider the services that customers need to be a very important factor relevant to the other factors.

The inter-quartile range (IQR) was calculated based on the input of the experts. Most factors have IQR values between 0 and 1 . This means that most responses are in broad agreement and show very little difference in the degree of the importance of each factor influencing decision-making in the servitization process. However, the political environment and supplier's negotiation power have IQR values of 2 and 1.75, respectively. Both factors have some different opinions among the experts.

Since Thailand has had political conflict for several years, political factors are important to the servitization decision in some industries, but are not very relevant or important in most industries. The different opinions concerning political factors arise from the various industries selected for the Delphi test. An IQR value of 2 shows a difference in value; the difference of opinion arises from the nature of each industry. The political factor remains a vital concern when considering servitization.

The supplier's negotiation factor yielded a mode score of 2, as it has some importance to the servitization concern. The $1^{\text {st }}$ quartile and $3^{\text {rd }}$ quartile are 2 and 4 , respectively. This indicates means that the degree of importance of suppliers ranges from somewhat important to very important. If the experts are from industries that have more negotiation power over their product's material suppliers, or they can develop a new service that depends less on their service-related suppliers, they rate the supplier factor as somewhat important. However, if the experts are from industries in which most product material suppliers have stronger power, or they need service-related suppliers to help them develop or provide new services to customers, they give a higher degree of importance to the supplier factor. Since the IQR value of 1.75 derives from the different nature of industries, supplier's negotiation power is considered a non-negligible factor for servitization for a broad range of industries.

From the statistical results, the median and mode show that all proposed factors are important to the servitization decision-making process. According to the IQR values, most factors are judged similarly. Only two factors show mild difference of opinion, which can be considered a normal deviation. Therefore, two rounds of the Delphi method are sufficient to support the findings of this study. However, if the proposed factors are to be applied in a specific industry, both political and supplier factors should be re-considered by including additional experts from that industry to weigh the importance of those factors.

\subsection{Survey: The Servitization Decision-Making Framework}

Figure 3 displays the survey data from 264 companies. 


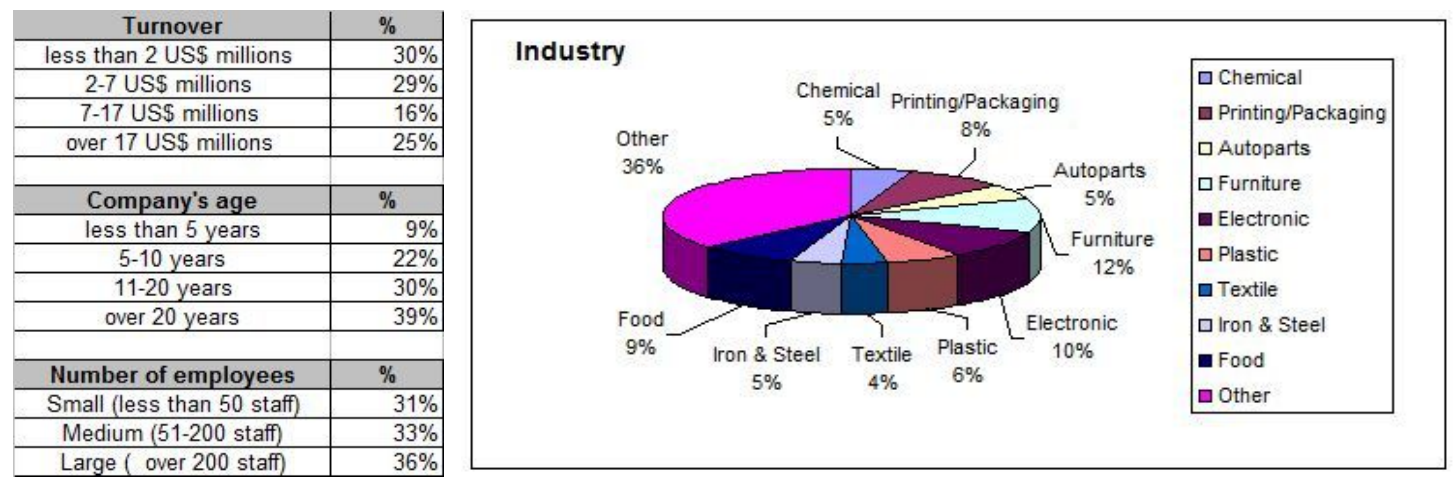

Figure 3. Characteristics of companies in the survey

The proposed factors weighted by 264 companies were calculated for median and standard deviation as shown in Figure 4.

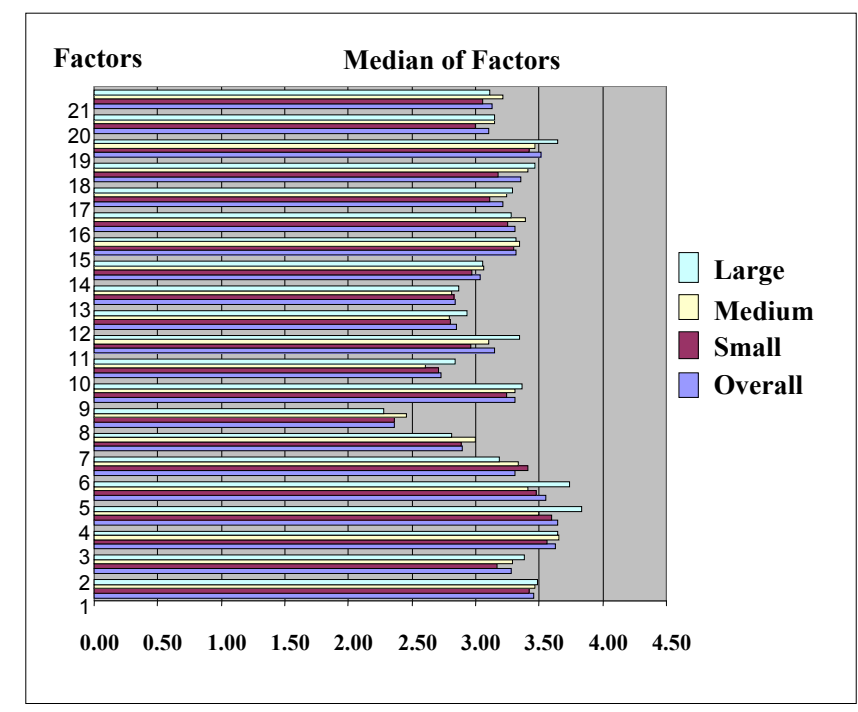

Figure 4. Median and standard deviation value of proposed factors from survey

The median of factors ranges from 2.29 to 3.65. This indicates that all factors are relevant and somewhat important to the servitization decision. Since each factor has a mode value of 3 or 4 , most surveyed companies consider each factor to be moderately to highly important. The political factor (factor 8) still shows the lowest median value at 2.29. It can be inferred from the Delphi method that despite the size of a company, the political factor is important in some industries but not in others. The highest median value of overall data is 3.65 for the factor of the service that customers want (factor 4), and vision and policy that management would like to deploy (factor 3). Both show a mode of 4 , confirming that both factors are very important for deciding on the path towards servitization.

Most factors yield standard deviation values (S.D.) of less than 1. This implies that most responses are in broad agreement and show very little difference in the relative weight in making decisions. However, the political factor (factor 8) has an S.D. value over 1; this indicates that this factor affects some industries but is not relevant to others. The political factor mode is 3 , which implies moderate importance to the servitization concern.

In summary, the median and mode show that all proposed factors are important to the servitization decision and S.D. values reveal that all factors are of equal concern to the servitization decision-making process. Therefore, the survey results confirm that the factors found in the literature review, case studies and Delphi method are the appropriate factors to evaluate decisions concerning servitization. 


\section{Discussion and Implications}

The findings presented in this paper are derived from several research practices. Based on the literature review, numerous factors are involved in making the servitization decision. This study has arranged the factors into groups, and categorized these as either internal or external. Some factors discussed in the literature have been discarded while some details have been added to the factors proposed in this study. After investigating the business cases, the proposed factors have been organized into a more suitable structure in terms of servitization concern and servitization readiness. The Delphi method and company surveys have been employed to verify the validity of the framework.

After confirmation with the Delphi method and survey, the servitization decision-making framework in Figure 5 presents the key factors that Thai companies should include when considering servitization.

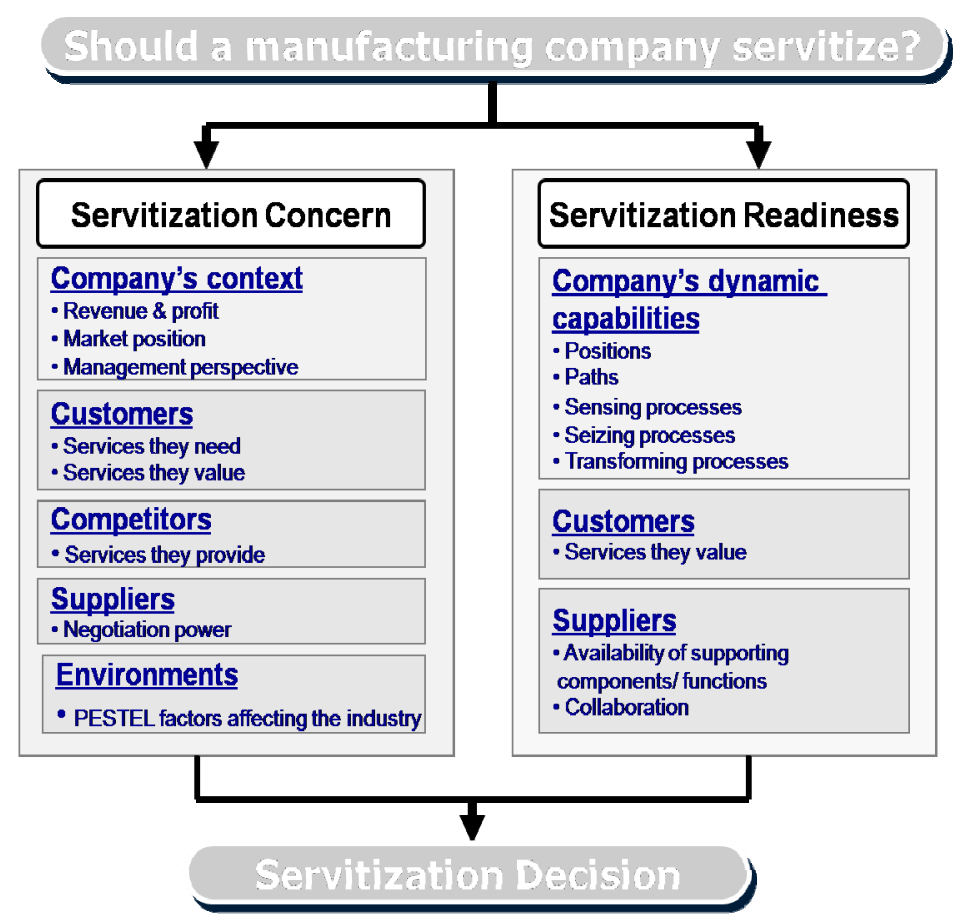

Figure 5. Conceptual framework of relevant factors for the servitization decision-making process

The framework presents two schemes of factors that companies may use to consider servitization: servitization concern and servitization readiness. Companies evaluate the need for servitization by investigating five key factors. First is the company's context, which comprises revenue and profit, market position and management perspective; these reflect a company's internal need for servitization. Exploring the services that customers want and appreciate is another critical element. Checking what services competitors offer and estimating the negotiation power between companies and their suppliers are also vital aspects of the servitization consideration process. Finally, using PESTEL factors to check aspects of the business environment that affect the industry completes the evaluation of servitization.

Servitization readiness is also vital to the success of servitization. Before deciding on servitization, a company should ensure that its dynamic capabilities, customers and suppliers are ready to support the new business direction. Companies can apply dynamic capabilities such as positions, paths, sensing processes, seizing processes and transforming processes to evaluate their internal readiness. Before providing any new service, companies should confirm whether or not customers value the new service offer. Finally, checking the availability of components and functions supporting servitization and generating strong collaboration with suppliers are significant for servitization readiness.

Normally, when servitization concern is high, it requires a company to servitize itself. However, the case studies reveal that some companies are ready to servitize before it is in need of service. Therefore, servitization concerns need not occur prior to a company's move towards servitization. Hence, the servitization decision-making 
framework consists of servitization concern and servitization readiness in parallel. By combining both factor sets together, companies will have a clearer framework for making their servitization decisions.

\section{Conclusion}

This research discusses the servitization decision-making processes of four leading companies in Thailand. Service is one of the major strategies that manufacturing firms in Thailand implement to retain their competitiveness. The servitization decision-making process requires several considerations and preparations. The proposed framework helps companies consider servitization more appropriately; however, this framework needs to be developed and tested with further case studies. More specific studies for particular industries with high servitization potential and needs will be developed in order to gain a more appropriate servitization decision-making framework relevant to particular industries.

\section{References}

Adner, R., \& Helfat, E. C. (2003). Corporate effects and dynamic managerial capabilities. Strategic Management Journal, 24, 1011-1025. http://dx.doi.org/10.1002/smj.331

Ambrosini, V., \& Bowman, C. (2009). What are dynamic capabilities and are they a useful construct in strategic management. International Journal of Management Reviews, 11(1), 29-49. http://dx.doi.org/10.1111/j.1468-2370.2008.00251.x

Baines, T. S., Lightfoot, H. W., Benedettini, O., \& Kay, J. M. (2009). The servitization of manufacturing: a review of literature and reflection on future challenges. Journal of Manufacturing Technology Management, 20(5), 547-567. http://dx.doi.org/10.1108/17410380910960984

Bandinelli, R., \& Gamberi, V. (2012). Servitization in oil and gas sector: outcomes of a case study research. $\begin{array}{llll}\text { Journal of Manufacturing Technology } & \text { Management, 23(1), }\end{array}$ http://dx.doi.org/10.1108/17410381211196302

Bask, A., Lipponen M., Rajahonka, M., \& Tinnila, M. (2011). Framework for modularity and customization: service perspective. Journal of Business and Industrial Marketing, 26(5), 306-319. http://dx.doi.org/10.1108/08858621111144370

Brady, T., Davies, A., \& Gann, D. M. (2005). Creating value by delivering integrated solutions. International Journal of Project Management, 23, 360-365. http://dx.doi.org/10.1016/j.ijproman.2005.01.001

Brax, S. (2005). A manufacturer becoming service provider - challenges and a paradox. Managing Service Quality, 15(2), 142-155. http://dx.doi.org/10.1108/09604520510585334

Correa, H. L., Ellram, L. M., Scavarda, A. J., \& Cooper, M. C. (2007). An operations management view of the service and goods mix. International Journal of Operations \& Production Management, 27(5), 444-463. http://dx.doi.org/10.1108/01443570710742357

Davies, A., Brady, T., \& Hobday, M. (2006). Charting a path towards integrated solutions. MIT Sloan Management Review, 43(7), 39-48.

Eisenhardt, K. M., \& Martin, J. A. (2000). Dynamic capabilities: what are they? Strategic Management Journal, 21, 1105-1121. http://dx.doi.org/10.1002/1097-0266(200010/11)21:10/11<1105::AID-SMJ133>3.0.CO;2-E

Gebauer, H., Bravo-Sanchez, C., \& Fleisch, E. (2008). Service strategies in product manufacturing companies. Business Strategy Series, 9(1), 12-20. http://dx.doi.org/10.1108/17515630810850073

Gebauer, H., Edvardsson, B., \& Bjurko, M. (2009). The impact of service orientation in corporate culture on business performance in manufacturing companies. Journal of Service Management, 21(2), 237-259. http://dx.doi.org/10.1108/09564231011039303

Gebauer, H., Fleisch, E., \& Friedli, T. (2005). Overcoming the service paradox in manufacturing companies. European Management Journal, 23(1), 14-26. http://dx.doi.org/10.1016/j.emj.2004.12.006

Gebauer, H., Paiola, M., \& Edvardsson, B. (2010). Service business development in small and medium capital goods manufacturing companies. Managing Service Quality, 20(2), 123-139. http://dx.doi.org/10.1108/09604521011027561

Gremyr, I., Lofberg, Ni., \& Witell, L. (2010). Service innovations in manufacturing firms. Managing Service Quality, 20(2), 161-175. http://dx.doi.org/10.1108/09604521011027589

Helander, A., \& Moller, K. (2008). System supplier's roles from equipment supplier to performance provider. $\begin{array}{llll}\text { Journal of Business and Industrial Marketing, 23(3), 577-585. } & \text {. }\end{array}$ 
http://dx.doi.org/10.1108/08858620810913380

Insead. (2011). Issues The Global Innovation Index 2011 Switzerland ranks first among 125 economies on innovation levels. Retrieved from http://www.insead.edu/media_relations/press_release/2011_global_innovation_index.cfm

Levitt, T. (1972). Production-line Approach to Service. Harvard Business Review, 50(5), 20-31.

Lockett, H., Johnson, M., Evans, S., \& Bastl, M. (2010). Product service systems and supply network relationships: an exploratory case study. Journal of Manufacturing Technology Management, 22(3), 293-313. http://dx.doi.org/10.1108/17410381111112684

Macmillan, T. (1971). The Delphi Technique. Paper presented at the Annual Meeting of the California Junior Colleges Associations Committee on Research and Development, Monterey, California.

Mathieu, V. (2001). Service strategies within the manufacturing sector: benefits, costs and partnership. International Journal of Service Industry Management, 12(5), 451-475. http://dx.doi.org/10.1108/EUM0000000006093

Menon, A. G., \& Mohanty, B. (2008). Towards a theory of "dynamic capability" for firms. Paper presented at the 6th AIMS International Conference on Management, New Delhi, India.

Mont, O. (2000). Product-service systems. Swedish Environmental Protection Agency, Stockholm, Sweden.

Neely, A. (2008). The servitization of manufacturing: an analysis of global trends. Paper presented at the 14th European Operations Management Conference, Ankara, Turkey.

Oliva, R., \& Kallenberg, R. (2003). Managing the transition from products to services. International Journal of Service Industry Management, 14(2), 160-172. http://dx.doi.org/10.1108/09564230310474138

Petroni, A. (1998). The analysis of dynamic capabilities in a competence-oriented organization. Technovation, 18(3), 179-189. http://dx.doi.org/10.1016/S0166-4972(97)00093-X

Reilly, M., \& Scott, P. S. (2010). Dynamic capabilities, absorptive capability and knowledge sharing: a research agenda into explicating the antecedent factors conducive to subsidiary bargaining power. Paper presented at the 37th Annual Conference of the Academy of International Business AIB-UKI (UK \& Ireland Chapter), Dublin, Ireland.

Sakao, T., Sandstrom, G. O., \& Matzen, D. (2009). Framing research for service orientation of manufacturers through PSS approaches. Journal of Manufacturing Technology Management, 20(5), 754-778. http://dx.doi.org/10.1108/17410380910961082

Skulmoski, G., Hartman, F., \& Krahn, J. (2007). The Delphi method for graduate research. Journal of Information Technology Education, 6(1), 1-21.

Teece, D. J. (2007). Explicating dynamic capabilities: The nature and microfoundations of (sustainable) enterprise performance. Strategic Management Journal, 28, 1319-1350. http://dx.doi.org/10.1002/smj.640

Teece, D. J., Pisano, G., \& Shuen, A. (1997). Dynamic capabilities and strategic management. Strategic $\begin{array}{llll}\text { Management } & \text { Journal, } & \text { 509-533. }\end{array}$ http://dx.doi.org/10.1002/(SICI)1097-0266(199708)18:7<509::AID-SMJ882>3.0.CO;2-Z

The World Bank. (2011). Thailand Now an Upper Middle Income Economy. Retrieved from http://www.worldbank.or.th/WBSITE/EXTERNAL/COUNTRIES/EASTASIAPACIFICEXT/THAILANDE XTN/0,,contentMDK:22974843 pagePK:1497618 piPK:217854 theSitePK:333296,00.html

Thompson, J. (2002). Strategic Management. London: Thomson.

Vandermerwe, S., \& Rada, J. (1988). Servitization of business: adding value by adding services. European Management Journal, 6(4), 314-324. http://dx.doi.org/10.1016/0263-2373(88)90033-3

Verona, G., \& Ravasi, D. (2003). Unbundling dynamic capabilities: an exploratory study of continuous product innovation. Industrial and Corporate Change, 12(3), 577-606. http://dx.doi.org/10.1093/icc/12.3.577

Zollo, M., \& Winter, S. G. (2002). Deliberate learning and the evolution of dynamic capabilities. Organization Science, 32(3), 339-351. http://dx.doi.org/10.1287/orsc.13.3.339.2780 